\title{
2. Tibetan MSS. in the Stein Collection.
}

\section{London.} August 17th, 1903.

Dear Professor Rhys Davids,-I am much indebted to Dr. Rockhill for the friendly remarks which he has made in the July number of the Journal anent my "Preliminary Notice" of the Stein Tibetan MSS. His chief arguments, however, if he will allow me to say so, seem to indicate some misapprehensions, which, with your permission, I will endeavour to remove.

Firstly, we have an archæological issue. My statement that " the conditious under which the fragments were discovered were such as to make it practically impossible to date them later than the eighth century, and the evidence of a Chinese sgraffito has since proved this conclusion to be right" was written after consultation with Dr. Stein himself. It expresses the views since set forth by the latter scholar in his newly published "Sand-Buried Ruins of Khotan" (Introduction, p. xix, and ch. xxvii). The Chinese sgraffito on the wall of the ruined temple of Endere, as read by Professor Chavannes and other Sinologists, gives as date 719 or 791 A.D., the earlier date being apparently the more probable; and Dr. Stein, speaking as. an archæological expert from observation on the spot and on the basis of wide experience elsewhere, decides that "the date when this Chinese sgraffito was scratched into the wall could not have preceded by many years the deposition of the various votive manuscripts," and that "this consideration (the nature of the plaster) fixes the second half of the eighth century as the latest possible time for the production of the Tibetan . . . manuscripts" (p. 419). These judgments, passed after critical study of all archæological evidence obtainable during the excavations and subsequently, will, I hope, convey assurance to Dr. Rockhill on the archæological issue.

The second issue is purely philological. I wrote that "the most novel and interesting feature in the spelling of 
the Sallistamba is the presence of a final $-d$ at the end of most of the roots which terminate in $-r,-l$, or $-n$," and "another singular feature is the presence of $y$ between $m$ and the high vowels $i$ and $e$." Apparently my words were open to misconstruction. Dr. Rockhill considers the $-d$ as a sporadic blunder in spelling; but as a matter of fact its presence is regular in the Śălistamba MS., with only isolated exceptions. Now I submit that when a carefully written MS., of which nearly a half survives, presents such forms as these with $-d$ not in isolated examples but by the dozen, ${ }^{1}$ with only exceptional deviations, ${ }^{2}$ the laws of textcriticism and philology alike compel us to accept them as either genuine archaisms or genuine dialectal phenomena.

Thus my theory that "the final $-d$ was beginning to be dropped in conversation, and was only preserved by literary tradition" still stands where it did; and the Do-ring inscription quoted by Dr. Rockhill incidentally confirms it. The Śalistamba MS., as I have said, keeps the literary tradition (whether national or local I do not pretend to say) by generally writing $-d$ after certain roots; among the other Stein MSS., one instance (sgrold) appears in a carelessly written copy of two poems, and the vulgar sgraffiti on the walls of the Endere temple, so far as they have been deciphered, have also but one example ('t'sald pai); and lastly in the Do-ring inscription of the ninth century it is entirely absent, precisely as one would expect. Plainly we have before us the gradual decay of a genuine form.

Again, it is to be noted that the final $-d$, though regularly kept by numerous roots in the Śâlistamba MS., is never under any circumstances found in a large number of other roots, as I pointed out. This fact surely disposes of Dr. Rockhill's theory that it is a mere "fault in spelling"; and it likewise debars us from supposing that the $-d$ was in origin a euphonic development, and that from this use it came later to be generalised; for why should it then be restricted rigidly to certain roots?

1 One page, for instance, has ten instances.

2 Dr. Rockhill wrongs the scribe in charging him with having written stsalr;. the MS. has plainly stsald. 
The insertion of $y$ after $m$ before $i$ and $e$ is another case in which I regret that I cannot accept Dr. Rockhill's view. It appears throughout in the Stein MSS. and sgraffiti; and, as Dr. Rockhill remarks, it occurs on the Do-ring too. Dr. Rockhill suggests that this insertion of $y$ is " an attempt, since abandoned, to differentiate, in certain cases, words with nearly the same sound"; thus mye 'fire,' but me t'og 'flower.' If I rightly understand Dr. Rockhill, he means that a word with two meanings received a $y$ in one case and not in another. Let the facts decide on this theory. $M i$, occurring in the two meanings 'not' and 'man,' is in either case spelt myi; and so with other words. Dr. Rockhill's theory equally breaks down before words like med, rmi, smin, which have only one meaning apiece, and yet are invariably written in the Stein MSS. as myed, rmyi, smyind. In view of these facts I must still adhere to my former opinions; and I venture to think that Dr. Rockhill would agree with me if he had been able to apply his learning to a study of the MSS. as a whole, as I hope he will do when they will be published in Dr. Stein's “Detailed Report."-Very sincerely yours,

\section{D. Barnett.}

\section{Cup-Marks as an Archaic Form of Inscription.}

Dear Professor Rhys Davids, - Reading Mr. RivettCarnac's article on the above subject in the July number of this Journal reminded me of similar cup-marks which I discovered eighteen years ago in the 'Isā Șomāli Country.

I mentioned the matter at a meeting of the Royal Geographical Society in 1885 ; but neither the late Sir Richard Burton nor anyone else present at the meeting could suggest. any explanation of the marks.

I also alluded to this in a letter to you, published in the R.A.S. Journal, April, 1898. To save the trouble of reference, I quote the paragraph :-

"Whatever be the origin of the Șomāli race, it is certain that their country, or at least the extreme western portion, 